\title{
Prototipe Sistem Pengelolaan Ujian Pendadaran Tugas Akhir Mahasiswa
}

\author{
Okkita Rizan $^{1}$, Silvia $^{2}$, Hengki $^{3}$, Hamidah $^{4}$, R. Burham Isnanto ${ }^{5 *}$ \\ 12,3 Jurusan Sistem Informasi STMIK Atma Luhur \\ ${ }^{4}$ Jurusan Manajemen Informatika STMIK Atma Luhur \\ 5 Jurusan Teknik Informatika STMIK Atma Luhur \\ Jln. Jend. Sudirman Pangkalpinang - Bangka Belitung \\ ${ }^{1}$ orizan@atmaluhur.ac.id \\ 21322500022@atmaluhur.ac.id \\ 3hengki@atmaluhur.ac.id \\ 4hamidah@atmaluhur.ac.id \\ 5burham@atmaluhur.ac.id
}

Intisari- Ujian akhir, yang biasa disebut dengan skripsi merupakan tahapan akhir bagi mahasiswa untuk menyelesaikan studinya. Faktor yang menjadi penentu seorang mahasiswa telah menyelesaikan skripsinya dengan baik adalah apabila telah lulus melewati tahapan yang disebut dengan ujian pendadaran atau sering disebut dengan sidang skripsi. Di Lingkungan akademik STMIK Atma Luhur, jadwal pelaksanaan sidang skripsi dilaksanakan secara serentak atau kolektif di penghujung akhir semester, selesai jadwal mahasiswa bimbingan dengan dosen pembimbing masing-masing. Pengumuman hasil sidang skripsi langsung disampaikan pada hari itu juga, setelah memperoleh hasil penilaian dari dewan penguji skripsi. Kendala yang sedang terjadi adalah timbulnya kesulitan bagi mahasiswa untuk melakukan proses pendaftaran sidang skripsi, dikarenakan harus datang ke kampus dan mengantri di Bagian Administrasi dan Akademik Kemahasiswaan. Kendala berikutnya jadwal penguji yang sering bentrok dikarenakan jadwal sidang masih disusun secara sederhana. Pada saat penyampaian hasil sidang skripsi sering juga mengalami keterlambatan, dikarenakan distribusi form hasil sidang skripsi cukup lama diantar dari BAAK ke ruang sidang. Penelitian ini disusun untuk membantu proses pengelolaan administrasi ujian pendadaran mahasiswa, meliputi kemudahan proses pendaftaran, penyusunan jadwal bagi mahasiswa dan dewan penguji dan pelaporan akhir. Tahapan sistem ini dikembangkan menggunakan model fast. Metode analisis dan desainnya dibantu menggunakan object oriented. Hasil penelitian menunjukkan sistem yang dibangun berbasis web ini, mampu mengatasi permasalahan yang timbul dari sistem yang sedang berjalan saat ini.

Kata kunci - skripsi, sidang pendadaran, metode object oriented, model prototipe, web.

Abstract-The final exam, commonly referred to as a thesis, is the final stage for students to complete their studies. The deciding factor of a student who has completed his thesis well is if he has passed the stage called the awareness test or often referred to as the thesis session. In the academic environment of STMIK Atma Luhur, the schedule for the implementation of the thesis session is carried out simultaneously or collectively at the end of the semester, finished the schedule of student guidance with their respective supervisors. Announcement of the results of the thesis trial was immediately delivered on the same day, after obtaining the results of the evaluation from the thesis examination board. The obstacle that is happening is the emergence of difficulties for students to do the thesis trial registration process, because they have to come to campus and queue at the Student Administration and Academic Section. The next obstacle is that the examiner's schedule often clashes because the trial schedule is still arranged in a simple way. At the time of submission of the results of the thesis session often also experience delays, due to the distribution of the results of the thesis trial is quite long delivered from BAAK to the courtroom. This study was structured to assist the administration of the student awareness examination management process, including the ease of the registration process, the preparation of schedules for students and the board of examiners and final reporting. This stage of the system was developed using the fast model. The method of analysis and design is assisted using object oriented. The results showed that this web-based system was able to overcome problems arising from the current system.

Keywords - thesis, thesis defence, object oriented methods, prototype model, web. 


\section{Pendahuluan}

Pada perguruan tinggi, skripsi merupakan mata kuliah wajib yang harus ditempuh oleh mahasiswa dan menjadi mata kuliah penentu, layak atau tidaknya seorang mahasiswa untuk yudisium dan wisuda. Skripsi biasanya ditempuh selama 1 (satu) semester penuh dan dilaksanakan di semester terakhir apabila mahasiswa sudah memenuhi kelayakan akademik untuk melaksanakan skripsi. Kelayakan seorang mahasiswa dapat mengikuti skripsi ditentukan oleh jumlah sks yang telah diperoleh dan harus lulus mata kuliah prasyaratnya.

Pada akhirnya, mata kuliah skripsi akan diujikan untuk menentukan layak atau tidak hasil mahasiswa tersebut diluluskan. Berbeda dengan mata kuliah lain yang proses pengujiannya biasa diukur dari beberapa nilai seperti presensi, tugas, uts dan uas mahasiswa, skripsi tidak demikian. Pengujian kelulusan mata kuliah skripsi mengharuskan mahasiswa untuk mempresentasikan dan mendemokan hasil skripsinya di depan dewan penguji. Proses ini biasa disebut dengan sidang pendadaran skripsi.

Di lingkungan STMIK Atma Luhur, sidang pendadaran skripsi dilaksanakan secara terjadwal dengan jangka waktu tertentu. Jangka waktu pelaksanaannya tergantung dengan jumlah mahasiswa yang mendaftar untuk mengikuti sidang. Jadwal sidang dibagi menjadi beberapa sesi waktu dengan menempati beberapa ruangan. Sidang dilaksanakan secara paralel dengan menyinkronkan jadwal pembimbing dan penguji supaya tidak bentrok. Butuh ketelitian dalam penyusunan jadwal sidangnya.

Melihat kondisi sistem yang sedang berjalan, penulis tertarik untuk meneliti proses pelaksanaan sidang ini. Ada beberapa permasalahan yang timbul, baik dari sisi mahasiswa, panitia dan dewan penguji, yang menjadikan penulis tertarik dengan topik ini. Dari sisi mahasiswa, permasalahan dimulai dari proses pendaftaran, mahasiswa diharuskan datang dan mengantri di baak, menyebabkan tidak efisiennya waktu. Permasalahan berikutnya juga jadwal sidang yang diperoleh mahasiswa masih bersifat selebaran yang ditempel di papan pengumuman kampus. Sekali lagi mahasiswa harus datang ke kampus melihat jadwalnya. Dari sisi panitia, mengharuskan ketelitian yang tinggi saat penyusunan jadwal sidangnya. Panitia harus memastikan, jadwal dosen pembimbing, penguji dan mahasiswa tidak bentrok satu sama lain. Dari jadwal yang sudah disusun, panitia harus mendistribusikan sendiri ke setiap mahasiswa, pembimbing dan penguji. Dari sisi dewan penguji, kesulitan timbul saat jadwal sidang yang dimilikinya hilang dan saat proses perhitungan nilai sidang bagi mahasiswa.

Solusi yang ditawarkan oleh peneliti untuk mengatasi permasalahan ini, di antaranya memperbaiki proses pendaftaran sidang dan informasi jadwal sidang bagi mahasiswa, memperbaiki proses penyusunan jadwal sidang dan pendistribusiannya. Bagi dewan penguji, solusi yang penulis rancang yaitu memudahkan informasi jadwal dan mempercepat proses perhitungan hasil sidang mahasiswa, sehingga tidak akan mengganggu jadwal sidang jam berikutnya.

Beberapa penelitian juga sudah pernah dirancang sebelumnya tentang pelaksanaan sidang pendadaran. Penelitian Pertama dilakukan oleh Muftia dengan judul Sistem Informasi Seminar dan Sidang Tugas Akhir Program Studi Teknik Informatika Universitas Tanjung pura yang menjelaskan tentang Sistem informasi ini dapat membantu proses monitoring tugas akhir mahasiswa dengan menampilkan informasi perkembangan tugas akhir, serta mendukung proses pelaksanaan seminar dan sidang tugas akhir. Hasil pengujian black box menunjukkan bahwa sistem dapat bekerja dengan baik dalam menangani suatu kemungkinan kesalahan.[1]

Penelitian kedua oleh I Putu Gede Budayasa dengan judul Optimasi Penjadwalan Seminar dan Sidang Tugas Akhir pada Sistem Informasi Tugas Akhir di STMIK STIKOM Indonesia yang menjelaskan tentang Optimasi penjadwalan seminar proposal dan sidang tugas akhir pada sistem informasi tugas akhir STMIK STIKOM 
Indonesia diterapkan dengan melalui tahapan pengkodean, menentukan populasi awal dan inisialisasi kromosom, fungsi fitness, proses seleksi, pindah silang (cross over), mutasi, hingga elitisme. Dari hasil implementasi diperoleh bahwa sistem informasi yang dibangun telah berhasil membantu pengelolaan tugas akhir dan menghasilkan penjadwalan seminar atau sidang.[2]

Penelitian ketiga oleh Arni Retno Mariana dengan judul Sistem Informasi Aplikasi Penilaian Sidang Skripsi Berbasis web di STMIK Bina Sarana Global yang menjelaskan tentang Berdasarkan hasil penelitian yang telah dilakukan oleh perancang dan user di bagian Prodi bahwa solusi pemecahan terhadap kendala - kendala yaitu dengan membuat sistem informasi aplikasi penilaian sidang skripsi berbasis web. Dengan adanya sistem permasalahan yang ada dapat diminimalisir. Dari segi waktu penginputan nilai lebih cepat, karena dosen pembimbing dan dosen penguji yang akan menginputkan langsung nilai ke dalam sistem, ketika nilai sudah masuk ke dalam sistem, sistem akan membuat berita acara sidang dan laporan secara otomatis. Karena sistem ini berbasis web, keunggulannya adalah tidak ada lagi permasalahan dalam waktu penginputan, karena dapat diakses kapan saja dan dimana saja. Dan penyimpanan data sudah menggunakan satu database sehingga tidak terpisah - pisah dan keamanan data lebih tinggi.[3]

Penelitian keempat oleh Neva Satyahadewi dengan judul Sistem Informasi Monitoring Tugas Akhir Berbasis Web yang menjelaskan tentang SIMTA dapat membantu dosen dan fakultas MIPA Universitas Tanjungpura untuk melakukan kontrol atau monitoring mahasiswa yang sedang melakukan tugas akhir, berdasarkan lamanya pengambilan tugas akhir maupun berdasarkan lama studi mahasiswa. Dengan adanya SIMTA, Fakultas MIPA memiliki pangkalan data tugas akhir mahasiswa dan rekam jejak tugas akhir mahasiswa, dan adanya pencatatan digital seminar proposal, seminar hasil, maupun sidang sarjana.[4]
Penelitian kelima oleh Frisilia Meiny Tuturoong dengan judul Rancang Bangun Sistem Informasi Proses Tugas Akhir yang menjelaskan Berdasarkan hasil penelitian telah dibangun suatu sistem informasi proses tugas akhir yang berbasis Web melalui beberapa proses antara lain penentuan business case, pembuatan arsitektur sistem, pengkodean, dan pengujian sistem. Sistem ini dapat digunakan oleh Dosen dan Mahasiswa untuk proses tugas akhir sehingga dapat memudahkan proses konsultasi dan bimbingan tugas akhir.[5]

\section{Metodologi Penelitian}

Dalam penelitian ini, penulis telah menyusun beberapa tahapan yang akan digunakan untuk merancang dan mendesain sistem usulan. Point pertama yang dilakukan penulis adalah pengambilan data yang terkait yang akan digunakan dalam penyusunan dan pengajuan proposal. Berikutnya diteruskan dengan mengambil sample data, penganalisian, perancangan sistem dan pembuatan data. Untuk memperoleh data yang berhubungan dengan kegiatan sidang skripsi, penulis melakukan wawancara dengan pihak terkait untuk memperoleh informasi yang akurat. Dalam proses desain sistem, penulis memanfaatkan beberapa literatur, yang dilakukan dengan menggunakan beberapa referensi dari buku, artikel dan jurnal. Dalam menganalisa untuk mendapatkan gambaran sistem yang sedang berjalan, penulis menggunakan activity diagram. Untuk mendesain basis data, penulis memanfaatkan diagram keterhubungan entitas. Untuk desain antar muka, penulis rancang untuk dapat digunakan oleh mahasiswa, panitia, dan dewan penguji.

Selesai tahapan perancangan sistem, yang berikutnya adalah pengujian sistem, pengujian yang digunakan dalam penelitian ini adalah menggunakan black box. Pengujian ini dilakukan untuk melihat apakah sistem informasi yang dirancangan sudah sesuai atau belum dan apakah fungsionalitas dari sistem dapat berjalan sesuai dengan yang dibutuhkan. 
Dalam penyusunan penelitian, penulis menggunakan tahapan dalam model FAST (Framework For the Application of System Thinking) dalam pengembangan perangkat lunaknya sesuai dengan kebutuhan penyelesaian penelitian yaitu scope definition, problem analysis, requirements analysis, decision analysis, logical desain, physical desain, logical desain dan testing. Beberapa tahapan menggunakan metode berorientasi objek terutama pada saat proses analisa dan desain sistem, juga menggunakan metode terstruktur dalam perancangan basis datanya. Dalam tahapan implementasi, penulis menyusun aplikasi menggunakan framework berbasis web dan mySQL untuk basis datanya.[6]

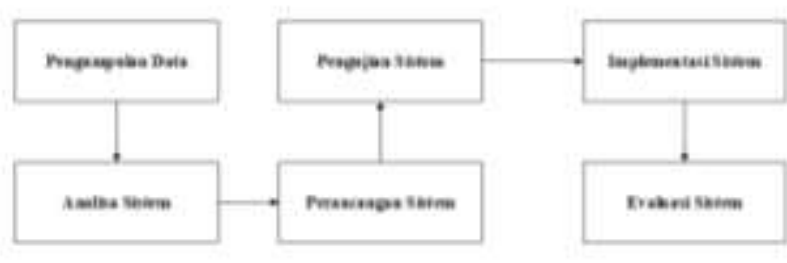

Gambar 1. Metodologi Penelitian

Penulis telah menyusun beberapa tahapan dalam penelitian ini. Langkah pertama yang dilaksanakan penulis yaitu pengambilan data yang dimulai dari menyusun proposal, mengajukan proposal dan diteruskan dengan mengambil data, analisis data, perancangan sistem sampai pembuatan sistem. Dalam pengumpulan data dilakukan dengan cara wawancara dengan tujuan untuk memperoleh informasi yang berkaitan dengan penyaluran raskin. Wawancara dilakukan dengan pihak personalia yang memang bertugas untuk mengurus segala keperluan yang berhubungan dengan sumber daya manusia, termasuk juga dalam proses perekrutan pegawai. Studi literatur dengan cara mencari referensi dari buku-buku, artikel dan jurnal sedangkan dokumentasi berjalan dengan cara menganalisa dokumen yang didapat dari personalia. Tahapan selanjutnya, perancangan sistem dimulai dengan penggambaran proses bisnis menggunakan activity diagram, rancangan basis data dengan menggunakan diagram keterhubungan entitas dan perancangan antar muka atau interface untuk sistem informasi yang akan digunakan oleh staff personalia dalam proses rektrutmen yang ditunjukkan dengan use case diagram dan implementasi antar muka dengan menggunakan aplikasi yang sudah dibuat.

Selesai tahapan perancangan sistem, yang berikutnya adalah pengujian sistem, pengujian yang digunakan dalam penelitian ini adalah menggunakan black box. Pengujian ini dilakukan untuk melihat apakah sistem informasi yang dirancangan sudah sesuai atau belum dan apakah fungsionalitas dari sistem dapat berjalan sesuai dengan yang dibutuhkan.

Dalam penyusunan penelitian, penulis menggunakan tahapan dalam model FAST (Framework For the Application of System Thinking) dalam pengembangan perangkat lunaknya sesuai dengan kebutuhan penyelesaian penelitian yaitu scope definition, problem analysis, requirements analysis, decision analysis, logical desain, physical desain, logical desain dan testing. Beberapa tahapan menggunakan metode berorientasi objek terutama pada saat proses analisa dan desain sistem, juga menggunakan metode terstruktur dalam perancangan basis datanya. Dalam tahapan implementasi, penulis menyusun aplikasi menggunakan framework berbasis web dan mySQL untuk basis datanya.

\section{HASIL DAN PEMBAHASAN}

Untuk menentukan rancangan model yang sesuai untuk sistem yang diusulkan, maka pembahasan disusun dimulai dari menganalisa sistem pengelolaan sidang skripsi yang sedang berjalan, sehingga berdasarkan analisa yang telah diperoleh, dapat ditentukan rancangan sistem yang diusulkan. 


\section{A. AnAlisa Sistem BerJalan}

Berdasarkan hasil survei dan studi lapangan, proses sidang pendadaran dimulai dari pendaftaran sidang oleh mahasiswa dengan periode waktu tertentu.

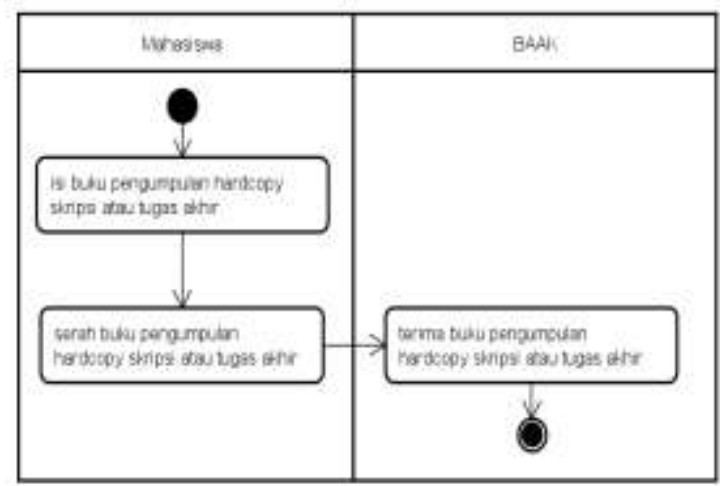

Gambar 2. Diagram Aktivitas Proses Pendaftaran Sidang Pendadaran

Proses berikutnya pihak panitia akan membuatkan jadwal setelah mendapatkan data dari prodi mengenai jumlah dosen yang ditunjuk sebagai dosen penguji dan bidang keahlian ujiannya. Selesai penyusunan, jadwal akan didistribusikan ke dosen penguji dan mahasiswa.

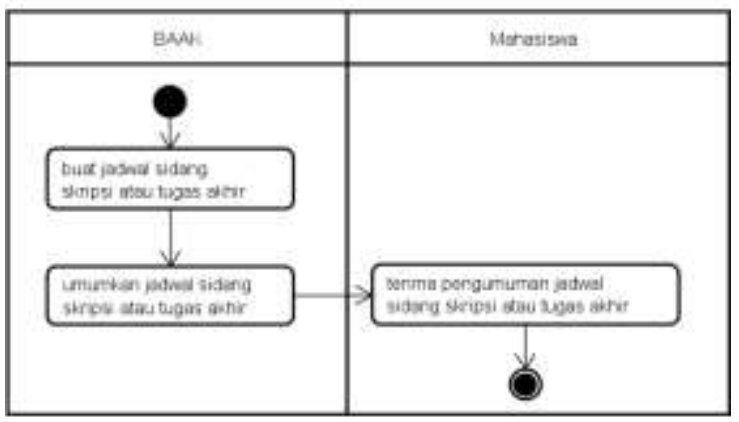

Gambar 3. Diagram Aktivitas Proses Pembuatan Jadwal Sidang

Pada saat sidang berlangsung, panitia akan menyiapkan form berita acara penilaian yang akan didiskusikan oleh penguji untuk menentukan nilai sidang mahasiswa. Pada saat itu akan langsung diumumkan.

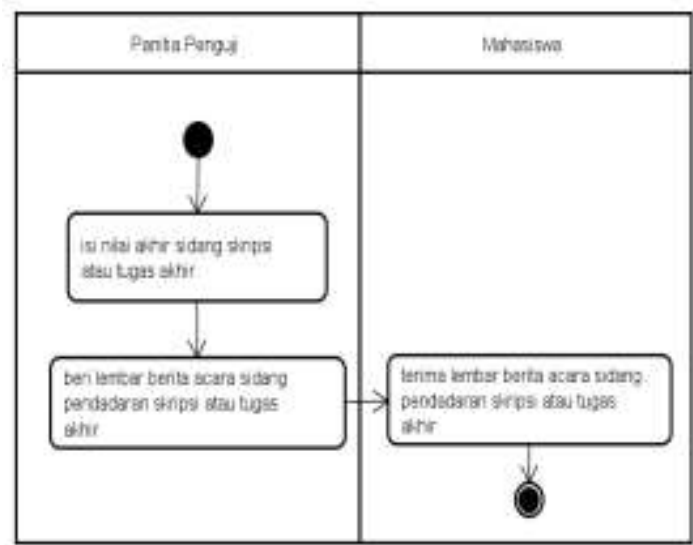

Gambar 4. Diagram Aktivitas Proses Penilaian Sidang Pendadaran

Mahasiswa diberi waktu untuk menyelesaikan revisi hasil sidang skripsinya. Bukti validasi perbaikan skripsi apabila form perbaikan skripsi sudah ditanda tangani oleh penguji dan pembimbing.

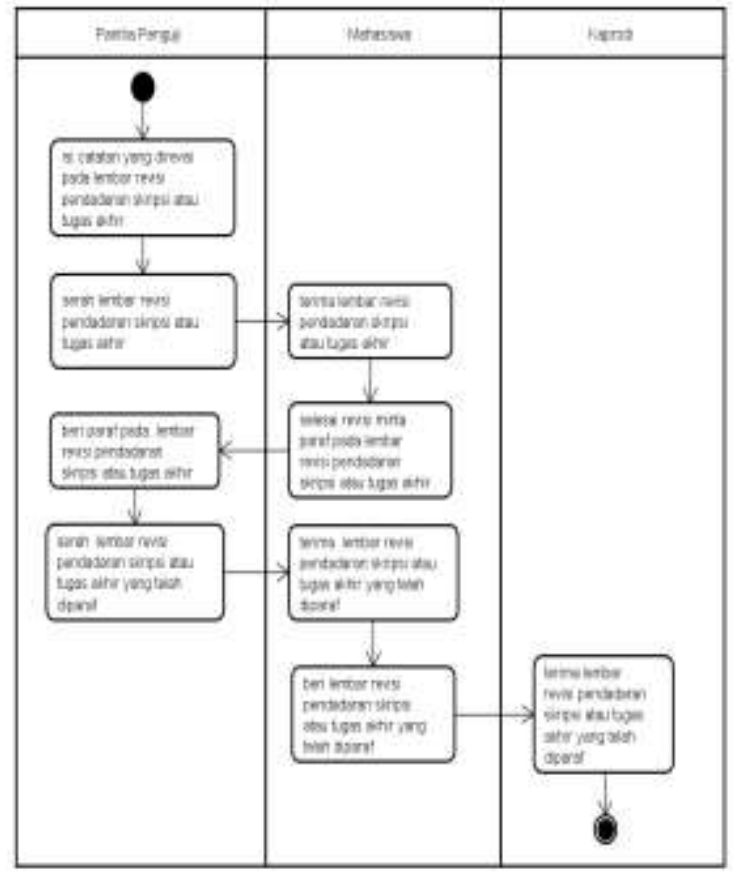

Gambar 5. Diagram Aktivitas Proses Revisi Hasil Sidang Pendadaran 


\section{B. DESAIN SISTEM USULAN}

Berdasarkan karakteristik proses dan hasil identifikasi permasalahan pada sistem berjalan, penelitian ini mengambil keputusan untuk membuat sebuah sistem informasi berbasis web dengan database yang secara realtime dapat di update. Keputusan ini diambil berdasarkan beberapa pertimbangan diantaranya adalah kemudahan dalam mengelola data peserta yang akan mengikuti sidang pendadaran, perekaman data yang lebih terstruktur dan mengurangi biaya operasional serta cepat dalam menyajikan laporan yang diperlukan dalam pengelolaan penjadwalan sidang pendadaran ini.

Untuk memudahkan penggunaan sistem dan validasinya, sistem yang diusulkan diperuntukkan oleh 4 (empat) user aktif, yaitu kaprodi, dosen penguji, panitia dan mahasiswa. Setiap pengguna diharuskan mempunyai form autentikasi sendiri yang akan menentukan form sesuai dengan kebutuhannya. Sistem yang diusulkan digambarkan menggunakan use case diagram dipecah menjadi 3 kategori, yaitu kategori proses pendataan awal, proses transaksi dan proses pelaporan.

Untuk kategori proses pendataan awal, user panitia mempunyai peranan untuk pengentrian data mahasiswa, data pembimbing dan ruangan. User Kaprodi bertugas untuk membuat topik yang akan digunakan dalam sidang sedangkan user mahasiswa dapat melakukan proses pendaftaran akun.

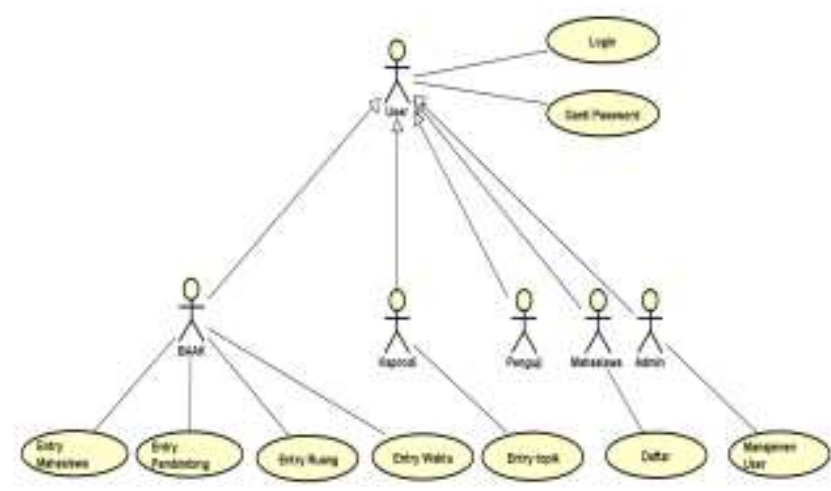

Gambar 6. Use Case Diagram Sistem Usulan Kategori Proses Pendataan Awal
Untuk kategori proses transaksi bagi user mahasiswa, sistem dirancang sehingga mahasiswa dapat melakukan proses pendaftaran sidang, dapat melihat jadwal sidangnya dan dapat mengetahui nilai yang telah diperolehnya.

Bagi user panitia, sistem dirancang sehingga panitia sidang dapat membantu mahasiswa melakukan proses pendaftaran, dapat memvalidasi laporan skripsi mahasiswa yang siap untuk disidang, sistem dapat membantu mendistribusikan jadwal sidang, berita acara penilaian dan form revisi mahasiswa.

Bagi user penguji, sistem dapat dirancang untuk dapat membantu dewan penguji dalam hal mengetahui jadwal sidangnya dan dapat mempermudah memberikan nilai dan catatan revisi setelah sidang pendadaran.

Bagi user kaprodi, sistem dirancang untuk menginput data dewan penguji sesuai dengan topik yang dikuasai.

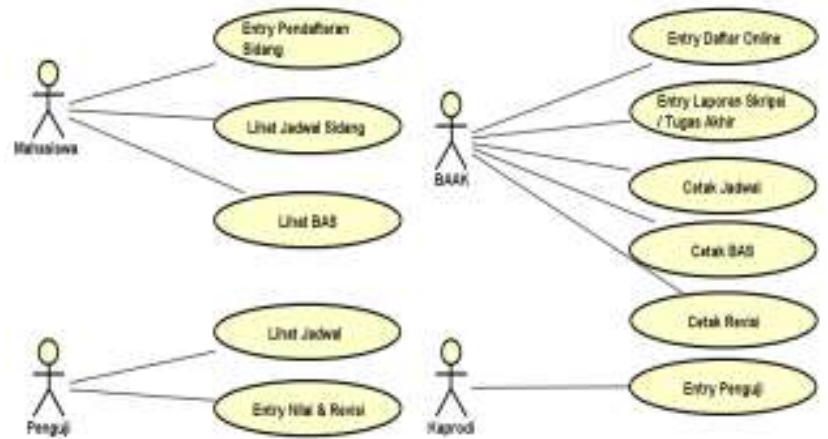

Gambar 7. Use Case Diagram Sistem Usulan Kategori Proses Transaksi

Untuk kategori proses pelaporan, dikhususkan untuk user panitia dengan sistem dapat membantu user untuk pelaporan peserta sidang, rekapitulasi hasil akhir sidang, pelaporan mahasiswa yang tidak lulus, pelaporan daftar dan jumlah bimbingan, serta dapat melaporkan jumlah penguji. 


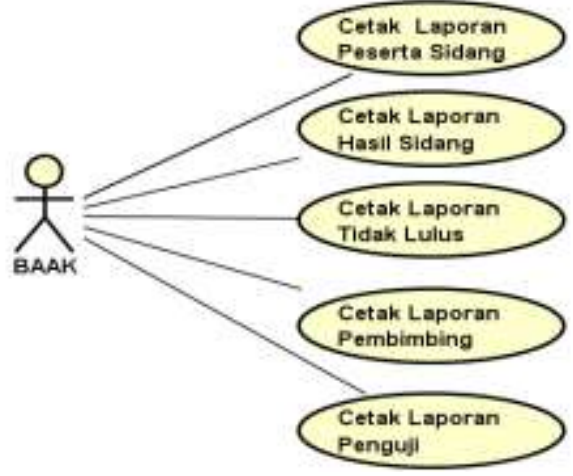

Gambar 6. Use Case Diagram Sistem Usulan Kategori Proses Pelaporan

Untuk basis datanya, dapat dilihat pada class diagram berikut. Basis data dirancang sedemikian rupa untuk dapat menangani kebutuhan sistem.

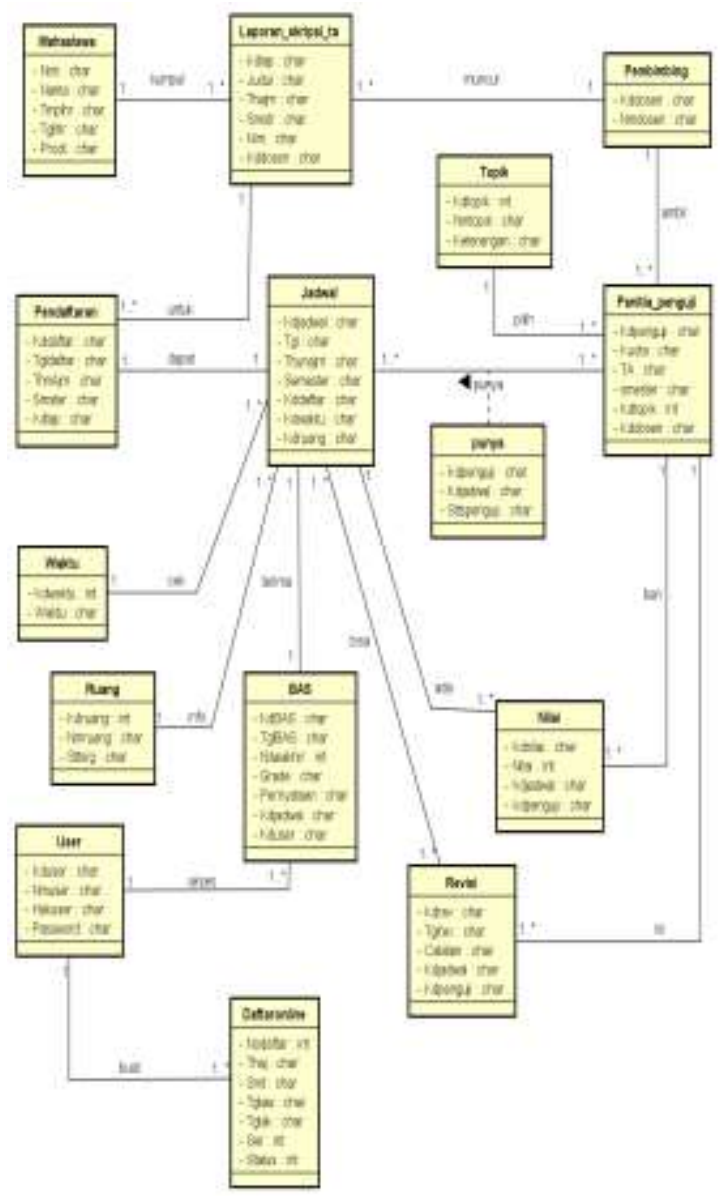

Gambar 7. Class Diagram Rancangan Basis Data
Berikut beberapa hasil implementasi dari rancangan desain sistemnya. Hasil yang dibuat mengikuti kebutuhan sistem yang telah ditunjukkan pada use case diagram diatas. Rancangan fisik yang dibuat menggunakan framework berbasis web. Framework ini dipilih untuk memudahkan proses desain interface sekaligus pada saat pembuatan koding programnya. Hasil implementasi berupa form untuk pendaftaran sidang, penjadwalan, entry nilai sidang dan hasil revisi.

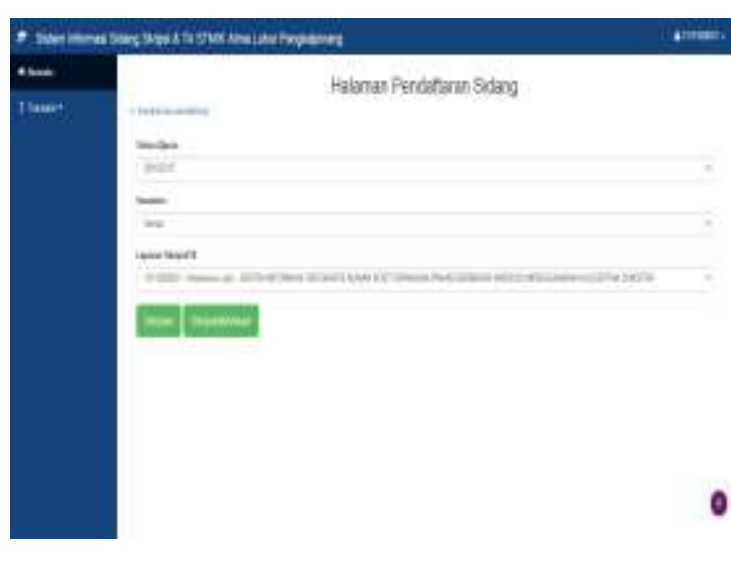

Gambar 8. Implementasi Form Pendaftaran Sidang

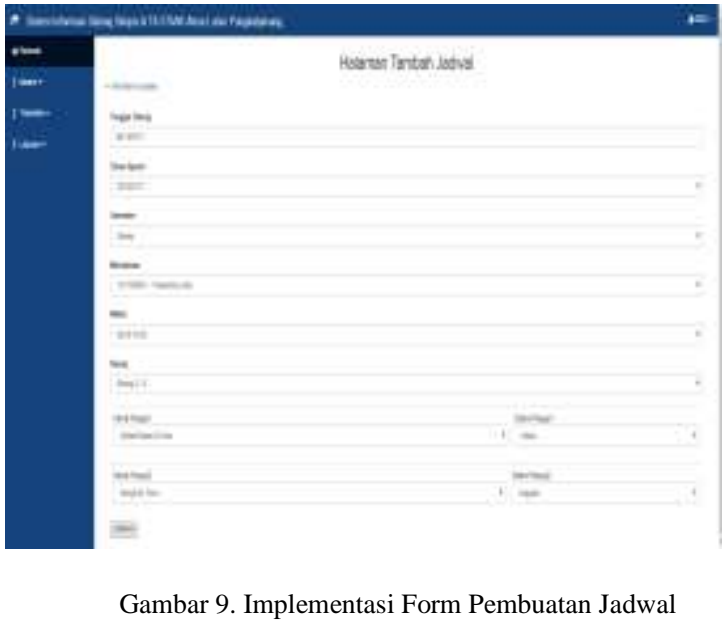




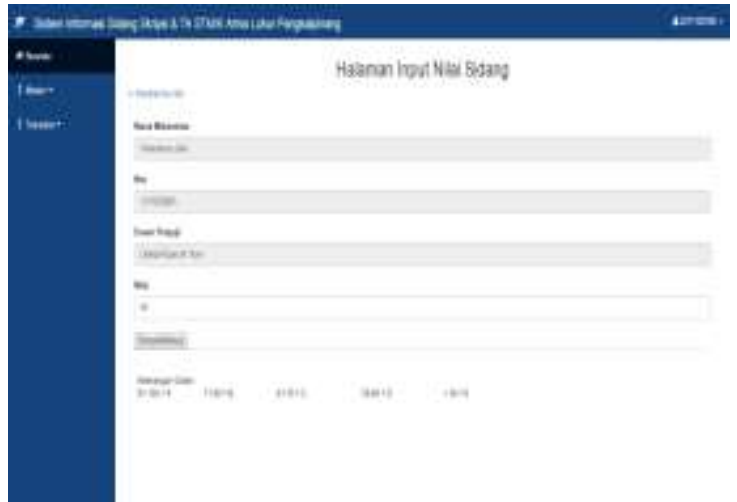

Gambar 10. Implementasi Form Penilaian Sidang Pendadaran

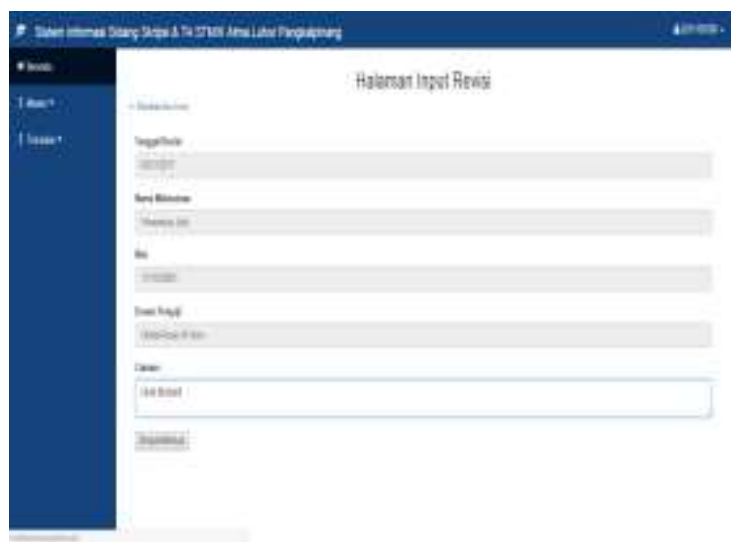

Gambar 11. Implementasi Form Catatan Revisi Sidang

\section{PENGUJIAN SISTEM}

Setelah program selesai dibuat, maka akan dilanjutkan pengujian terhadap sistem ini. Pengujian ini dimaksudkan untuk mengetahui seberapa jauh program tersebut berjalan dan seberapa banyak kesalahan yang ada pada program tersebut. Bila terjadi kesalahan, maka program tersebut akan segera diperbaiki dan diuji kembali. Pada tahap ini, peneliti menggunakan metode pengujian unit dengan pendekatan blackbox testing. Cara pengujian yang dilakukan dengan menjalankan aplikasi dengan melakukan input data dan melihat outputnya apakah sudah sesuai dengan proses atau hasil yang diharapkan[7]
Tabel 1. Pengujian Sistem Usulan

\begin{tabular}{|c|c|c|c|c|}
\hline $\begin{array}{c}\text { Pengujia } \\
n\end{array}$ & $\begin{array}{l}\text { Data } \\
\text { Input }\end{array}$ & Skenario & Hasil & Ket \\
\hline \multirow[t]{2}{*}{ Konten } & Benar & $\begin{array}{c}\text { Konten diisi } \\
\text { dengan lengkap } \\
\text { dan sesuai lalu } \\
\text { tekan tombol } \\
\text { simpan }\end{array}$ & $\begin{array}{c}\text { Data } \\
\text { Tersimpan }\end{array}$ & Sesuai \\
\hline & Salah & $\begin{array}{c}\text { Konten diisi } \\
\text { dengan tidak } \\
\text { lengkap dan ada } \\
\text { yang tidak sesuai }\end{array}$ & $\begin{array}{c}\text { Menampilka } \\
\mathrm{n} \text { message } \\
\text { kesalahan } \\
\text { yang harus } \\
\text { diperbaiki }\end{array}$ & Sesuai \\
\hline \multirow[t]{2}{*}{ Slide } & Benar & $\begin{array}{c}\text { Slide diisi dengan } \\
\text { lengkap dan sesuai } \\
\text { lalu tekan tombol } \\
\text { simpan }\end{array}$ & $\begin{array}{c}\text { Data } \\
\text { Tersimpan }\end{array}$ & Sesuai \\
\hline & Salah & $\begin{array}{l}\text { Slide diisi dengan } \\
\text { tidak lengkap dan } \\
\text { ada yang tidak } \\
\text { sesuai }\end{array}$ & $\begin{array}{l}\text { Menampilka } \\
\text { n message } \\
\text { kesalahan } \\
\text { yang harus } \\
\text { diperbaiki }\end{array}$ & Sesuai \\
\hline \multirow[t]{2}{*}{$\begin{array}{c}\text { Pesan } \\
\text { Validasi }\end{array}$} & Benar & $\begin{array}{c}\text { Pesan Validasi } \\
\text { diisi dengan } \\
\text { lengkap dan sesuai } \\
\text { lalu tekan tombol } \\
\text { simpan }\end{array}$ & $\begin{array}{c}\text { Data } \\
\text { Tersimpan }\end{array}$ & Sesuai \\
\hline & Salah & $\begin{array}{c}\text { Pesan Validasi } \\
\text { diisi dengan tidak } \\
\text { lengkap dan ada } \\
\text { yang tidak sesuai } \\
\text { Menampilkan }\end{array}$ & $\begin{array}{l}\text { Menampilka } \\
\text { n message } \\
\text { kesalahan } \\
\text { yang harus } \\
\text { diperbaiki }\end{array}$ & Sesuai \\
\hline \multirow[t]{2}{*}{ Footer } & Benar & $\begin{array}{l}\text { Footer diisi dengan } \\
\text { lengkap dan sesuai } \\
\text { lalu tekan tombol } \\
\text { simpan } \\
\text { Data }\end{array}$ & $\begin{array}{c}\text { Data } \\
\text { Tersimpan }\end{array}$ & Sesuai \\
\hline & Salah & $\begin{array}{c}\text { Footer diisi dengan } \\
\text { tidak lengkap dan } \\
\text { ada yang tidak } \\
\text { sesuai }\end{array}$ & $\begin{array}{c}\text { Menampilka } \\
\mathrm{n} \text { message } \\
\text { kesalahan } \\
\text { yang harus } \\
\text { diperbaiki }\end{array}$ & Sesuai \\
\hline
\end{tabular}

\section{KESIMPULAN}

Dari pembahasan yang telah diuraikan sebelumnya, dapat diambil beberapa kesimpulan yang berkaitan dengan sistem rekrutmen tenaga kependidikan yaitu sebagai berikut :

1. Sistem yang dirancang untuk menjalankan proses pengelolaan ujian sidang pendadaran sangat membantu agar proses pendaftaran, penjadwalan, dan penentuan hasil sidang tidak terlalu lama, serta memberikan kemudahan dalam penyampaian pelaporan.

2. Pengarsipan data rekrutmen tidak lagi membutuhkan banyak kertas dan tempat penyimpanan karena sudah tersimpan di dalam 


\section{sebuah Database Management Systems} (DBMS).

3. Dilakukan pengujian sistem rekrutmen tenaga kependidikan menggunakan blackbox testing. Pengujian dilakukan dengan cara menjalankan aplikasi yang sudah ada.

\section{REFERENSI}

[1] Muftia, dkk. Sistem Informasi Seminar dan Sidang Tugas Akhir Program Studi Teknik Informatika Universitas Tanjungpura. JUSTIN,Vol 1,No 1, 2016.

[2] I Putu Gede Budayasa, dkk. Optimasi Penjadwalan Seminar dan Sidang Tugas Akhir pada Sistem Infrmasi Tugas Akhir di STMIK STIKOM Indonesia.Jurnal Ilmu Komputer dan sains terapan Vol 5, No 2, April 2015,hal 96-105.

[3] Arni Retno Mariana, dkk. Sistem Informasi Aplikasi Penilaian Sidang Skripsi Berbasis web di STMIK Bina Sarana Global. Jurnal Sisfotek Global, Vol 3, No 2, September 2013.

[4] Neva Satyahadewi, dkk.Sistem Informasi Monitoring Tugas Akhir Berbasis Web. Journal of Computer Engineering System and Science Vol 4, No 1 Januari 2019.

[5] Frisilia Meiny Tuturoong, dkk. Rancang Bangun Sistem Informasi Proses Tugas Akhir. E-journal Teknik Informatika, Vol 8, No 1, 2016.

[6] Okkita Rizan, 2016, Sistem Informasi Penjadwalan Dosen Ajar Studi Kasus : STMIK Atma Luhur, Jurnal, STMIK Atma Luhur, Pangkalpinang.

[7] Pressman, Roger S. 2002. Rekayasa Perangkat Lunak Pendekatan Praktisi (Buku I). Yogyakarta: Penerbit Andi. 